\title{
Choroby mitochondrialne - co powinien wiedzieć kardiolog?
}

\author{
Mitochondrial diseases: what the cardiologist should know?
}

\author{
Olga Zdończyk ${ }^{1}$ (D), Biruta Kierdaszuk ${ }^{2}$ (D), Katarzyna Kurnicka ${ }^{1}$ (D), Piotr Pruszczyk ${ }^{1}$ (D) \\ ${ }^{1}$ Klinika Chorób Wewnętrznych i Kardiologii Warszawskiego Uniwersytetu Medycznego \\ ${ }^{2}$ Katedra i Klinika Neurologii Warszawskiego Uniwersytetu Medycznego
}

\section{Streszczenie}

Miopatie mitochondrialne (MD) są heterogenną grupą rzadkich chorób uwarunkowanych genetycznie charakteryzującą się defektem mitochondrialnego łańcucha oddechowego z następowym zaburzeniem metabolizmu energetycznego komórek. Ze względu na istotną zależność serca od metabolizmu oksydacyjnego jego zajęcie w MD jest częste i może występować zarówno jako część choroby wieloukładowej, jak i główny objaw kliniczny. Wszystkie struktury serca mogą być dotknięte przez chorobę, ale najczęściej dochodzi do zajęcia miokardium. Najczęstszą manifestacją zajęcia serca w MD są kardiomiopatie, jednak nieprawidłowości w układzie sercowo-naczyniowym u tych pacjentów pozostają zróżnicowane i mogą się objawiać jako zaburzenia rytmu serca lub przewodzenia, niewydolność serca (HF), nadciśnienie płucne, poszerzenie aorty wstępującej oraz obecność płynu w worku osierdziowym. Zajęcie serca u pacjentów z MD ma charakter postępujący, wiąże się z gorszym rokowaniem i zwiększoną śmiertelnością z powodu HF. Może ono jednak pozostawać bezobjawowe aż do osiągnięcia zaawansowanego stadium z powodu ograniczonej mobilności pacjentów, dlatego badania przesiewowe w kierunku kardiomiopatii oraz zaburzeń rytmu serca powinny być częścią standardowego postępowania w tej grupie. Wszyscy pacjenci z zajęciem serca, także bez objawów, powinni być skierowani do kardiologa z doświadczeniem i znajomością postępowania w przypadkach MD.

Słowa kluczowe: choroby mitochondrialne, kardiomiopatia mitochondrialna, zajęcie serca, zaburzenia przewodzenia

Folia Cardiologica 2020; 15, 2: 122-129

\section{Wstęp}

Miopatie mitochondrialne (MD, mitochondrial diseases) są heterogenną grupą rzadkich chorób uwarunkowanych genetycznie charakteryzującą się defektem mitochondrialnego łańcucha oddechowego z następowym zaburzeniem metabolizmu energetycznego komórek. Mimo że objawy moga dotyczyć niemal każdego organu, szczególnie podatne są tkanki o wysokim zapotrzebowaniu energetycznym, takie jak tkanka nerwowa i mięśniowa, jak również mięsień sercowy [1]. Obecnie nie ma pełnych badań epidemiologicznych, w których oceniono by liczbę pacjentów z MD w Polsce, a podobne dane są także trudno dostępne na świecie. Powikłania kardiologiczne, takie jak niewydolność serca (HF, heart failure), zaburzenia rytmu serca i przewodzenia oraz nagły zgon sercowy, pozostają jedną z głównych przyczyn umieralności w tej grupie chorych [1, 2]. Zgodnie z wytycznymi neurologicznych i kardiologicznych towarzystw naukowych pacjenci z chorobami nerwowo-mięśniowymi, w tym z MD, powinni pozostawać pod opieką zarówno neurologiczną, jak i kardiologiczną [3]. Kardiolodzy będą coraz częściej angażowani w wielodyscyplinarną opiekę nad tymi pacjentami i dlatego powinni znać podstawy patofizjologii zaburzeń leżących u podłoża tej grupy chorób, cechy kliniczne oraz spektrum objawów z układu sercowo-naczyniowego.

\section{Etiopatogeneza}

Mitochondrialny łańcuch oddechowy podlega podwójnej kontroli - DNA mitochondrialnego (mtDNA, mitochondrial 
DNA) oraz jądrowego (nDNA, nuclear DNA) - dlatego MD są spowodowane defektami zarówno mtDNA, jak i nDNA [1, 4]. Zaburzenia mtDNA są przyczyną większości (ok. 70\%) przypadków MD u dorosłych [5, 6]. Kontrola przez dwa genomy sprawia, że MD mogą być dziedziczone zgodnie z prawami genetyki mitochondrialnej, a więc w linii od matki, a także w sposób autosomalny recesywny, autosomalny dominujący lub sprzężony z chromosomem X [4]. Mutacje mtDNA mogą także powstawać de novo [4]. Występują one w ponad 1/200 żywych urodzeń, co czyni je jednymi z najczęstszych patogennych alleli w populacji ogólnej [7]. Warto jednak podkreślić, że obecność mutacji nie musi prowadzić do choroby, jako że większość mutacji mtDNA ma charakter heteroplazmatyczny, ze zmienną ilością zmutowanego mtDNA w obrębie poszczególnych komórek, a do defektu łańcucha oddechowego dochodzi po przekroczeniu progu wynoszącego zazwyczaj 60-90\% zmutowanego mtDNA w stosunku do mtDNA typu dzikiego [8]. Szacuje się, że częstość występowania MD u dorosłych - w tym zarówno mutacji mtDNA, jak i nDNA - wynosi około 1/4300, zatem należą one do jednych z najczęstszych dziedzicznych zaburzeń nerwowo-mięśniowych [9].

\section{Obraz kliniczny}

Ze względu na obecność mitochondriów we wszystkich komórkach jądrzastych choroba może dotykać wielu różnych tkanek i objawiać się szerokim spektrum postaci klinicznych, od skąpoobjawowych, obejmujących jeden narząd (np. głuchota lub cukrzyca), po złożone wieloobjawowe zespoły zajmujące kilka układów i narządów (ryc. 1). Objawy mogą się pojawić na każdym etapie życia, a wiek, w którym występują,

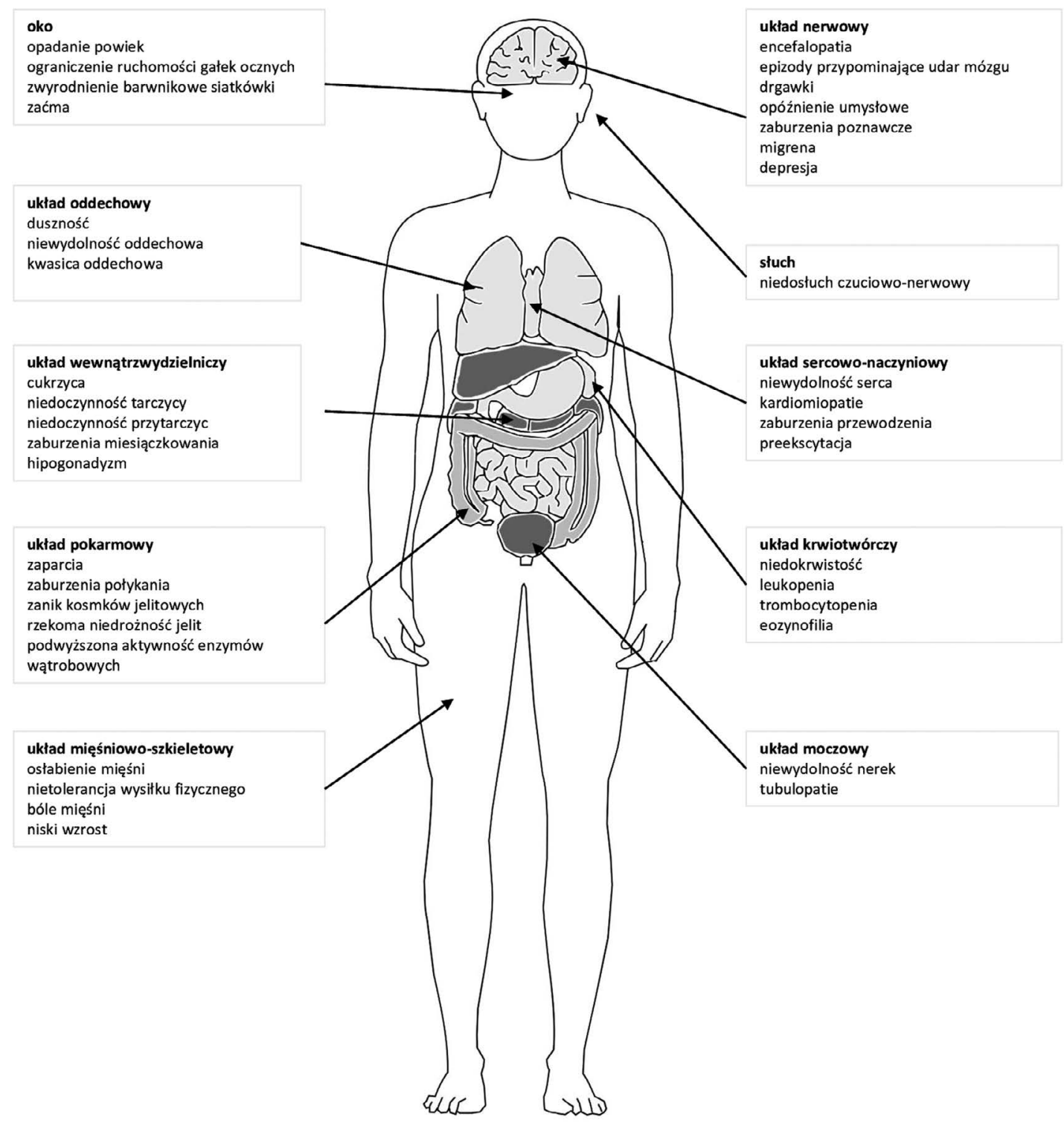

Rycina 1. Objawy chorób mitochondrialnych 
Tabela 1. Wybrane zespoły mitochondrialne (na podstawie $[8,10,11]$ )

\begin{tabular}{|c|c|c|c|}
\hline Zespół & Mutacja & Cechy kliniczne & Manifestacje kardiologiczne \\
\hline \multicolumn{4}{|c|}{ Choroby o początku objawów w wieku niemowlęcym lub dzieciństwie } \\
\hline $\begin{array}{l}\text { Zespół } \\
\text { Leigha }\end{array}$ & Mutacje mtDNA oraz nDNA & $\begin{array}{l}\text { Podostra martwicza encefalomielopatia, } \\
\text { opóźnienie rozwoju psychoruchowego }\end{array}$ & $\begin{array}{l}\text { HCM, DCM, LVNC, zaburzenia } \\
\text { przewodzenia, płyn w osierdziu }\end{array}$ \\
\hline KSS & Delecje mtDNA & $\begin{array}{c}\text { Oftalmoplegia zewnętrzna, zwyrodnienie } \\
\text { barwnikowe siatkówki }\end{array}$ & $\begin{array}{l}\text { Szybko postępujące zaburzenia } \\
\text { przewodzenia, WPW, DCM, LVNC }\end{array}$ \\
\hline \multicolumn{4}{|c|}{ Choroby o początku objawów w wieku nastoletnim lub dorosłości } \\
\hline CPEO & $\begin{array}{l}\text { Mutacje punktowe oraz delecje } \\
\text { mtDNA, mutacje nDNA }\end{array}$ & $\begin{array}{c}\text { Postępujące osłabienie mięśni okorucho- } \\
\text { wych z ptozą, osłabienie mięśni proksy- } \\
\text { malnych, dysfagia }\end{array}$ & HCM, zaburzenia przewodzenia \\
\hline LHON & $\begin{array}{l}\text { Mutacje mtDNA }(11778 \mathrm{G}>\mathrm{A} \\
\text { 3460G }>\text { A i } 14484 \mathrm{~T}>\mathrm{C})\end{array}$ & Ostra lub podostra utrata wzroku & $\begin{array}{l}\text { LVNC, WPW, wydłużenie } \\
\text { odstępu QT }\end{array}$ \\
\hline MELAS & $\begin{array}{l}\text { Mutacja punktowa } 3243 A>G \\
\text { w obrębie genu MTTL1 (80\%) }\end{array}$ & $\begin{array}{l}\text { Encefalomiopatia mitochondrialna z kwa- } \\
\text { sicą mleczanową i epizodami przypomi- } \\
\text { nającymi udar mózgu zazwyczaj } \\
\text { przed 40. rż. }\end{array}$ & $\begin{array}{l}\text { HCM (przerost koncentryczny, bez } \\
\text { LVOTO), DCM, LVNC, WPW }\end{array}$ \\
\hline MERRF & $\begin{array}{l}\text { Mutacja punktowa } 8344 A>G \\
\text { w obrębie genu MTTK (80\%) }\end{array}$ & $\begin{array}{l}\text { Padaczka miokloniczna, miopatia, } \\
\text { ataksja móżdżkowa }\end{array}$ & DCM, HCM, WPW, SVT \\
\hline NARP & $\begin{array}{c}\text { Mutacja punktowa 8993T>G } \\
\text { w obrębie genu MTATP6 }\end{array}$ & $\begin{array}{c}\text { Neuropatia czuciowa, ataksja móżdżko- } \\
\text { wa, zwyrodnienie barwnikowe siatkówki, } \\
\text { zaburzenia rozwoju umysłowego, otępie- } \\
\text { nie, napady drgawkowe }\end{array}$ & $\begin{array}{l}\mathrm{HCM} \text {, kardiomiopatia połogowa, } \\
\text { preekscytacja }\end{array}$ \\
\hline
\end{tabular}

na ogół odzwierciedla poziom mutacji oraz zaawansowanie defektu biochemicznego [8]. Najbardziej podatne na nieprawidłową czynność mitochondriów są tkanki i narządy o wysokim zapotrzebowaniu energetycznym (tj. mózg, oko, serce, mięśnie szkieletowe) [1]. Częste objawy wspólne dla MD to postępująca oftalmoplegia zewnętrzna, ptoza, miopatia proksymalna, osłabienie, nietolerancja wysiłku fizycznego oraz bóle mięśni [4]. U wielu pacjentów występują liczne objawy układające się w sposób, który pozwala na wyróżnienie około 50 zespołów (tab. 1) [8, 10, 11], jednak większość stanowią chorzy z niespecyficznymi mitochondrialnymi zespołami zaburzeń wielonarządowych (ang. nonspecific mitochondrial multiorgan disorder syndromes), trudnymi do klasyfikacji i stanowiącymi istotne wyzwanie diagnostyczne dla klinicystów.

\section{Zaburzenia kardiologiczne u chorych z miopatiami mitochondrialnymi}

Mitochondria stanowią około 35\% objętości komórki mięśnia sercowego, a zachodząca w nich fosforylacja oksydacyjna jest głównym źródłem energii w sercu i odpowiada za prawie całą produkcję trifosforanu adenozyny (ATP, adenosine triphosphate) (>95\%). Ze względu na tak istotną zależność serca od metabolizmu oksydacyjnego zajęcie serca w MD jest częste i może występować zarówno jako część choroby wieloukładowej, jak i główny objaw kliniczny. W metaanalizie obejmującej 825 chorych zaburzenia strukturalne w standardowej echokardiografii przezklatkowej (TTE, transthoracic echocardiography) stwierdzono u 29\%, głównie u osób z encefalomiopatią mitochondrialną z kwasicą mleczanową i epizodami przypominającymi udar mózgu (MELAS, mitochondrial encephalomyopathy, lactic acidosis and stroke-like episodes) oraz padaczką miokloniczną z obecnością włókien szmatowatych (MERRF, myoclonic epilepsy with ragged-red fibers) oraz z mutacjami najczęściej z nimi związanymi (m.3243A>G oraz m.8344A>G) [12]. Wszystkie struktury serca moga być dotknięte przez chorobę, ale najczęściej dochodzi do zajęcia miokardium [13]. Najczęstszą manifestacją zajęcia serca są kardiomiopatie [14], jednak nieprawidłowości w układzie sercowo-naczyniowym u pacjentów z MD są zróżnicowane i obejmują także zaburzenia rytmu serca i przewodzenia, niewydolność serca, nadciśnienie płucne, poszerzenie aorty wstępującej oraz obecność płynu w worku osierdziowym [13]. 


\section{Kardiomiopatie}

Kardiomiopatia mitochondrialna charakteryzuje się nieprawidłową zarówno strukturą, jak i funkcją mięśnia sercowego, wtórnie do zaburzeń genetycznych mitochondrialnego łańcucha oddechowego, przy braku współistniejącej choroby wieńcowej, nadciśnienia tętniczego lub wady zastawkowej [15]. Fenotyp i przebieg kardiomiopatii mogą być bardzo zróżnicowane.

Najczęstszy typ kardiomiopatii mitochondrialnej to postać z przerostem mięśnia lewej komory (LVH, left ventricular hypertrophy), ale opisano także kardiomiopatię rozstrzeniową (DCM, dilated cardiomyopathy), restrykcyjną, z niescalenia lewej komory (LVNC, left ventricular noncompaction cardiomyopathy), takotsubo oraz histiocytoidalną [13]. Częstość występowania kardiomiopatii mitochondrialnej nie jest znana, ale szacuje się, że występuje u 20-40\% dzieci [14] oraz ponad $20 \%$ dorosłych z MD [6] i może dotyczyć co najmniej 1/10-15 tys. osób w populacji ogólnej [5].

Spektrum objawów klinicznych jest bardzo szerokie od ich braku, aż po stany zagrażające życiu, takie jak HF, tachyarytmie komorowe oraz nagła śmierć sercowa. Zazwyczaj objawy pogłębiają się w warunkach kryzysu metabolicznego, spowodowanego przez stresory fizjologiczne (np. gorączka) lub przez operacje chirurgiczne i może to prowadzić do rozwoju ostrej HF [15]. Do wystąpienia kryzysu metabolicznego mogą przyczyniać się także leki, które zakłócają funkcjonowanie łańcucha oddechowego (leki potencjalnie szkodliwe zamieszczono w tab. 2) [15]. Objawom kardiomiopatii mitochondrialnej często towarzyszą symptomy pochodzące z wielu innych układów (ryc. 1), ale może być ona również pierwszym lub jedynym objawem MD [14].

Postać z przerostem mięśnia lewej komory (LV, left ventricle) może występować u nawet 20\% pacjentów [6, 12, 17] i najczęściej jest obserwowana u osób z m.3243A>G, wśród których LVH może dotykać ponad połowy (> 50\%) [12, 18]. Przerost LV ma w tych przypadkach charakter głównie koncentryczny $[6,18]$, a zwężenie drogi odpływu LV występuje rzadko $[6,17]$. Upośledzenie funkcji skurczowej LV ma tendencję do progresji w czasie [6]. Postać z LVH może imitować kardiomiopatię przerostową (HCM, hypertrophic cardiomyopathy), która u 60\% dorosłych pacjentów wynika z mutacji genów sercowych białek sarkomeru, jednak do $10 \%$ przypadków jest spowodowanych innymi schorzeniami genetycznymi, w tym MD [19]. Dziedziczenie w linii matczynej, ale także charakterystyczne objawy, takie jak głuchota czuciowo-nerwowa, w szczególności współwystępująca z cukrzycą, zaburzenia widzenia, opadanie powiek

Tabela 2. Leki potencjalnie szkodliwe w chorobach mitochondrialnych (MD, mitochondrial diseases) (opracowano na podstawie [15, 16])

\begin{tabular}{|c|c|c|}
\hline Lek/grupa leków & Możliwe powikłania & Postępowanie \\
\hline Statyny & Miopatia, rabdomioliza & $\begin{array}{c}\text { Należy unikać simwastatyny, preferowane stosowanie } \\
\text { atorwastatyny z zachowaniem ostrożności i monitorowa- } \\
\text { niem stężenia kinazy kreatynowej }\end{array}$ \\
\hline Beta-adrenolityki & Mogą nasilać objawy MD & $\begin{array}{c}\text { Nie ma wystarczających dowodów wskazujących na to, } \\
\text { że należy ich unikać }\end{array}$ \\
\hline Amiodaron & Uszkodzenie mięśni & Stosować z zachowaniem ostrożności i monitorowaniem \\
\hline Spironolakton & $\begin{array}{l}\text { Uszkodzenie mięśni, } \\
\text { kwasica mleczanowa }\end{array}$ & $\begin{array}{c}\text { objawów klinicznych oraz stężeń mleczanów } \\
\text { i kinazy kreatynowej }\end{array}$ \\
\hline Amiloryd & $\begin{array}{l}\text { Uszkodzenie mięśni, } \\
\text { kwasica mleczanowa }\end{array}$ & \\
\hline Kortykosteroidy & Uszkodzenie mięśni & \\
\hline Inhibitory prostaglandyn & Uszkodzenie mięśni, kwasica mleczanowa & \\
\hline Metformina & Kwasica mleczanowa & $\begin{array}{c}\text { Stosować z zachowaniem ostrożności i monitorowaniem } \\
\text { stężenia mleczanów }\end{array}$ \\
\hline Kwas walproinowy & Niewydolność wątroby, stan padaczkowy & Należy unikać \\
\hline Propofol & Zespół propofolowy & $\begin{array}{l}\text { Krótkotrwałe stosowanie wydaje się bezpieczne, należy } \\
\text { unikać długotrwałego stosowania i dużych dawek }\end{array}$ \\
\hline \multicolumn{3}{|l|}{ Antybiotyki } \\
\hline Linezolid & Kwasica mleczanowa & Należy unikać, szczególnie u pacjentów z MELAS \\
\hline Chloramfenikol & Ostre zapalenie wątroby, dyskrazja krwi & $\begin{array}{l}\text { Niskie ryzyko powikłań, ale jeżeli to możliwe preferowane } \\
\text { podanie alternatywnego leku }\end{array}$ \\
\hline Aminoglikozydy & Utrata słuchu & Należy unikać \\
\hline
\end{tabular}


i osłabienie mięśni, powinny sugerować kardiologom prawdopodobną etiologię mitochondrialną.

Rzadszą postacią jest DCM. Najczęściej obserwuje się ją w efekcie progresji istniejącego wcześniej LVH z pogorszeniem czynności skurczowej serca, powiększeniem LV oraz zmniejszeniem grubości ściany LV, chociaż może być także pierwszą manifestacją zajęcia serca u pacjentów z MD [20]. W grupie z m.8344A>G częstość występowania DCM wynosi ponad 20\% [21], jednak u pacjentów z innymi mutacjami jest znacznie niższa $[6,22]$ i wynosi niecałe 5\% [22].

Kardiomiopatię z niescalenia lewej komory opisano w wielu MD, między innymi w MELAS, zespole Kearnsa-Sayre'a (KSS, Kearns-Sayre syndrome), zespole Leigha [23] czy dziedzicznej neuropatii nerwu wzrokowego Lebera (LHON, Leber's hereditary optic neuropathy) [24], ale także u pacjentów z niespecyficznymi mitochondrialnymi zespołami zaburzeń wielonarządowych [25]. Kardiomiopatia z niescalenia lewej komory występuje u niewielkiej grupy dorosłych z MD (ok. 3\%) [6], jednak ze względu na fakt, że MD to grupa zaburzeń genetycznych najczęściej związana z występowaniem LVNC [25], u osób z rozpoznaną LVNC należy wysunąć podejrzenie MD.

Bardzo rzadkim typem kardiomiopatii arytmogennej powiązanym z MD jest kardiomiopatia histiocytoidalna, zwana też dysplazją włókien Purkinjego, charakteryzująca się występowaniem nieprawidłowych kardiomiocytów i komórek Purkinjego przypominających histiocyty [12]. Dotyka ona zazwyczaj dzieci, częściej dziewczynek, chociaż została także opisana u dorosłych [26]. Objawia się zaburzeniami rytmu serca i nagłym zgonem sercowym [27] oraz może współistnieć z LVNC [26, 27].

\section{Zaburzenia rytmu i przewodzenia}

Nieprawidłowości w elektrokardiografii (ECG, electrocardiography) obserwuje się u nawet $70 \%$ pacjentów z MD [6], najczęściej z m.3243A>G oraz MELAS [10], częściej w populacji pediatrycznej [10]. Arytmie lub omdlenia, które wymagają wszczepienia urządzenia lub leczenia inwazyjnego, obserwowano u ponad 12\% pacjentów [6].

Zaburzenia przewodzenia występują dość często w MD ( 10\%) [6, 18, 28], a częstość ich występowania wzrasta z wiekiem podobnie jak w populacji ogólnej [5]. Najbardziej narażeni na zaburzenia przewodzenia są pacjenci z KSS [15], u których są one najczęstszym objawem zajęcia serca - dotyczą ponad $60 \%$ chorych [29] i mogą szybko postępować do całkowitego bloku przedsionkowo-komorowego (AV, atrioventricular block) $[29,30]$ lub związanego z bradykardią polimorficznego częstoskurczu komorowego [31].

Preekcytacja i zespół Wolffa-Parkinsona-White'a (WPW, Wolff-Parkinson-White syndrome) występują u 15-20\% pacjentów $[6,21,28]$ i najczęściej są związane z m.8344A>G i m.3243A>G (odpowiedzialnych, odpowiednio, za większość przypadków pacjentów z MERRF i MELAS) [6, 21, 28], ale opisano je również u pacjentów z zespołem przewlekłej postępującej zewnętrznej oftalmoplegii (CPEO, chronic progressive external ophthalmoplegia), neuropatią obwodową z ataksją i zwyrodnieniem barwnikowym siatkówki (NARP, neuropathy, ataxia and retinitis pigmentosa) - [6], LHON [24] oraz KSS [29], a także z niespecyficznymi mitochondrialnymi zespołami zaburzeń wielonarządowych [6]. W przypadkach z LHON zespół WPW może współistnieć z LVNC [24].

Najczęstszą nadkomorową arytmią w MD jest migotanie przedsionków, natomiast trzepotanie przedsionków jest opisywane rzadko [13].

Częstoskurcze komorowe u pacjentów z MD występują przede wszystkim w populacji pediatrycznej oraz u pacjentów z kardiomiopatiami [5]. Torsade de pointes często opisuje się w KSS, może się wiązać z wydłużeniem odstępu QT oraz omdleniami i postępować do bloku AV i zatrzymania krążenia [13].

\section{Biomarkery sercowe}

U pacjentów z MD obserwuje się podwyższone wartości troponin sercowych. W grupie 42 chorych będących pod opieką ośrodka autorów niniejszej pracy u $43 \%$ wartości troponiny T oznaczanej metodą wysokoczułą (hsTnT, high-sensitive troponin T) są umiarkowanie podwyższone, stabilne, nawet do $0,045 \mathrm{ng} / \mathrm{ml}$. Konieczne są dalsze badania służące wyjaśnieniu, czy podwyższone stężenia troponiny w MD są markerem uszkodzenia serca czy, podobnie jak u innych pacjentów z chorobami nerwowo-mięśniowymi [32], mogą być wynikiem uszkodzenia mięśni.

\section{Rokowanie i naturalny przebieg choroby}

Zajęcie serca u pacjentów z MD jest częste, ma postępujący charakter [6] i wiąże się z gorszym rokowaniem i zwiększoną śmiertelnością z powodu HF [17, 21]. Głównym czynnikiem wpływającym na przebieg naturalny choroby i ciężkość fenotypu ma wiek, w którym u pacjenta dokonano rozpoznania $[11,21]$. W grupie 113 pediatrycznych pacjentów z MD przeżywalność do 16. roku życia u dzieci z kardiomiopatią i bez niej wynosiła odpowiednio 18\% i 95\% [33]. Wydaje się, że kardiomiopatia u dorosłych przebiega łagodniej i lepiej rokuje [6, 22]. W 7-letniej obserwacji 260 pacjentów u 10\% z nich wystąpił punkt końcowy (nagły zgon, zgon z powodu HF, zresuscytowane zatrzymanie krążenia, blok AV III , dysfunkcja węzła zatokowego, transplantacja serca lub hospitalizacja z powodu HF). Niezależnymi predyktorami punktu końcowego były blok przewodzenia śródkomorowego, cukrzyca, przedwczesne pobudzenia komorowe i przerost mięśnia lewej komory, 
a częstość występowania poważnych zdarzeń sercowo-naczyniowych (MACE, major adverse cardiac event) u pacjentów nieobciążonych żadnym czynnikiem ryzyka oraz u obarczonych jednym, dwoma lub większą liczbą czynników ryzyka, wynosiła - odpowiednio - 1\%, 7\%, 15\% i aż 42\% [17]. Przerost mięśnia lewej komory był jedyną zmienną związaną z wystąpieniem zdarzenia w analizie wieloczynnikowej u pacjentów z m.3243A>G, a w trakcie obserwacji trwającej 3 -9 lat (mediana 5 lat) $25 \%$ pacjentów zmarło, w tym $7 \%$ z powodu HF, a u $17 \%$ stwierdzono zagrażające życiu zdarzenia sercowo-naczyniowe (hospitalizacje z powodu ciężkiej HF i zresuscytowane zatrzymanie krążenia) [28].

\section{Diagnostyka}

Zgodnie z wytycznymi [34] badania przesiewowe w kierunku kardiomiopatii oraz zaburzeń rytmu serca powinny być częścią standardowego postępowania u pacjentów z MD, w szczególności u pacjentów z MELAS i MERRF [10], którzy powinny być monitorowani w kierunku przerostu LV oraz DCM [13] ze względu na ich częstsze występowanie oraz wyższe ryzyko nagłej śmierci sercowej [28]. Zaleca się coroczne kontrole obejmujące ocenę za pomocą ECG oraz TTE, nawet w przedobjawowej fazie choroby, gdy standardowe ECG jest prawidłowe [3, 34, 35], mając na uwadze fakt, że zajęcie serca może pozostać bezobjawowe nawet do osiągnięcia zaawansowanego etapu [36], często z powodu ograniczonej mobilności pacjentów.

Analiza odkształcenia mięśnia sercowego metodą śledzenia markerów akustycznych w TTE wydaje się obiecującą metodą pomocną $w$ diagnozowaniu subklinicznego uszkodzenia serca u pacjentów z MD [36] - wykazano obniżoną wartość globalnego odkształcenia podłużnego oraz odkształcenia podłużnego w projekcji dwujamowej w porównaniu z grupą kontrolną, mimo że funkcja skurczowa mierzona $w$ trakcie konwencjonalnego TTE pozostawała w granicach normy [37]. Monitorowanie metodą Holtera zaleca się u pacjentów obciążonych wysokim ryzykiem preekscytacji i/lub zaburzeń przewodzenia (także tych bezobjawowych), znacznie upośledzoną funkcją skurczową LV oraz częstymi napadowymi objawami sugerującymi zajęcie serca [34, 35]. Rezonans magnetyczny serca (CMR, cardiovascular magnetic resonance) może być przydatny u pacjentów z suboptymalnymi warunkami obrazowania w TTE lub u tych, u których potrzebna jest bardziej dokładna ocena przez podjęciem decyzji terapeutycznych [35, 36]. W ocenie za pomocą CMR zajęcie serca dotyczy ponad 50\% pacjentów z MD [37, 38], a najczęstszym znaleziskiem jest późne wzmocnienie pokontrastowe (LGE, late-gadolinium enhancement) o etiologii nieniedokrwiennej. U pacjentów z CPEO/KSS obszary LGE mają lokalizację śródmięśniową w segmentach podstawnych ściany dolno-bocznej LV [38, 39], a u pacjentów z MELAS obserwuje się koncentryczny LVH z rozsianymi, śródmięśniowymi obszarami LGE [38]. Łączna ocena chorych z mitochondriopatiami za pomocą ECG, TTE, CMR oraz analizy odkształceń wykazała częstość występowania zajęcia serca u aż 80\% pacjentów [37].

\section{Postępowanie}

Wszyscy pacjenci z MD i zajęciem serca, także niewykazujący objawów, powinni być skierowani do kardiologa $z$ doświadczeniem i znajomością postępowania w tej grupie [34, 35]. U pacjentów z HF w przebiegu kardiomiopatii mitochondrialnej zasadne wydaje się stosowanie aktualnych wytycznych leczenia HF, jako że obserwowano znaczną poprawę funkcji LV po zastosowaniu standardowej terapii [20]. U wykazujących objawy pacjentów z kardiomiopatią z LVH rozważne wydaje się stosowanie zaleceń leczenia HCM [19], ale niektórzy autorzy, mając na uwadze postępujący charakter tej postaci kardiomiopatii, zalecają rozpoczęcie leczenia beta-adrenolitykiem lub antagonistą wapnia oraz inhibitorem konwertazy angiotensyny lub antagonistą receptora dla angiotensyny u wszystkich pacjentów, także tych bez objawów [5, 35].

Zważywszy na ryzyko szybkiej progresji zaburzeń przewodzenia u pacjentów z chorobami nerwowo-mięśniowymi, w tym z MD, a w szczególności z KSS, ważne jest wczesne rozpoznanie dowolnego stopnia bloku AV (w tym bloku ${ }^{\circ}$ ) i rozważenie wszczepienia układu do stałej stymulacji serca [3, 34, 35]. U pacjentów z blokiem AV III ${ }^{\circ}$ lub zaawansowanym blokiem $I^{\circ}$ zaleca się wszczepienie układu do stałej stymulacji niezależnie od umiejscowienia anatomicznego bloku [3]. U pacjentów z preekscytacją zaleca się badanie elektrofizjologiczne oraz rozważenie ablacji cewnikowej drogi dodatkowej [35]. Zaleca się, aby chorych z MD, u których występują komorowe zaburzenia rytmu, leczyć tak samo jak pacjentów bez chorób nerwowo-mięśniowych [3].

\section{Leczenie}

Dotychczas nie jest dostępna terapia MD i pozostaje tylko leczenie objawowe. Duże nadzieje są wiązane z nową substancją elamipretydem - tetrapeptydem wiążącym kardiolipinę w wewnętrznej błonie mitochondrium, który w badaniu obejmującym 36 pacjentów po 5 dniach dożylnego stosowania wydłużał dystans chodu średnio o 64,5 m [40]. Obecnie trwa III faza badania MMPOWER-3 (A Phase 3 Randomized, Double-Blind, Parallel-Group, Placebo-Controlled Trial to Evaluate the Efficacy and Safety of Daily Subcutaneous Injections of Elamipretide in Subjects with Primary Mitochondrial Myopathy Followed by an Open-Label Treatment Extension-GB), w którym są oceniane jego skuteczność i bezpieczeństwo. 


\section{Podsumowanie}

Zajęcie serca u pacjentów z MD jest częste, ma postępujący charakter i wiąże się z gorszym rokowaniem i zwiększoną śmiertelnością. Może także pozostawać bezobjawowe aż do osiągnięcia zaawansowanego stadium z powodu ograniczonej mobilności pacjentów. Badania przesiewowe w kierunku kardiomiopatii oraz zaburzeń rytmu serca powinny być częścią standardowego postępowania u pacjentów z MD. Potrzebne są dalsze badania pozwalające na wykrywanie przedklinicznego zajęcia serca, wczesne rozpoznanie i zastosowanie leczenia w odpowiednim momencie skutkującego poprawą rokowania w tej grupie pacjentów.

\section{Konflikt interesów}

Autorzy nie zgłaszają konfliktu interesów.

\section{Abstract}

Mitochondrial diseases (MD) are a heterogeneous group of rare genetically determined disorders, characterized by mitochondrial respiratory chain defect and subsequent energy metabolism imbalance. Due to almost exclusive aerobic metabolism of the heart, cardiac involvement in MD is common and can be accompanied by other manifestations of the multi-organ involvement, but may be also the first or the sole clinical manifestation of MD. All tissues of the heart may be affected but the most frequently affected tissue is the myocardium. The most frequent cardiac manifestation found in MD are cardiomyopathies, but cardiac abnormalities may be varied and include arrhythmias, heart failure, pulmonary hypertension, aortic root dilation, and pericardial effusion. Given the progressive nature of cardiac involvement in $\mathrm{MD}$, its association with poor prognosis and increased mortality, and the fact that it can remain asymptomatic until an advanced stage is reached, often due to limited patient mobility, cardiac screening should be a part of standard management of MD patients. All patients with cardiac involvement should be reviewed by a cardiologist with an expertise in the management of such patients.

Key words: mitochondrial disease, mitochondrial cardiomyopathy, cardiac involvement, conduction system disease

Folia Cardiologica 2020; 15, 2: 122-129

\section{Piśmiennictwo}

1. Pfeffer G, Chinnery PF. Diagnosis and treatment of mitochondrial myopathies. Ann Med. 2013; 45(1): 4-16, doi: 10.3109/07853890. 2011.605389, indexed in Pubmed: 21867371.

2. Majamaa-Voltti K, Turkka J, Kortelainen ML, et al. Causes of death in pedigrees with the $3243 \mathrm{~A}>\mathrm{G}$ mutation in mitochondrial DNA. J Neurol Neurosurg Psychiatry. 2008; 79(2): 209-211, doi: 10.1136/ /jnnp.2007.122648, indexed in Pubmed: 18202211.

3. Priori SG, Blomström-Lundqvist C, Mazzanti A, et al. ESC Scientific Document Group. 2015 ESC Guidelines for the management of patients with ventricular arrhythmias and the prevention of sudden cardiac death: The Task Force for the Management of Patients with Ventricular Arrhythmias and the Prevention of Sudden Cardiac Death of the European Society of Cardiology (ESC). Endorsed by: Association for European Paediatric and Congenital Cardiology (AEPC). Eur Heart J. 2015; 36(41): 2793-2867, doi: 10.1093/eurheartj/ehv316, indexed in Pubmed: 26320108.

4. Ahmed ST, Craven L, Russell OM, et al. Diagnosis and treatment of mitochondrial myopathies. Neurotherapeutics. 2018; 15(4): 943-953, doi: 10.1007/s13311-018-00674-4, indexed in Pubmed: 30406383.

5. Bates MGD, Bourke JP, Giordano C, et al. Cardiac involvement in mitochondrial DNA disease: clinical spectrum, diagnosis, and management. Eur Heart J. 2012; 33(24): 3023-3033, doi: 10.1093/ /eurheartj/ehs275, indexed in Pubmed: 22936362.

6. Limongelli G, Tome-Esteban M, Dejthevaporn C, et al. Prevalence and natural history of heart disease in adults with primary mitochondrial respiratory chain disease. Eur J Heart Fail. 2010; 12(2): 114-121, doi: 10.1093/eurjhf/hfp186, indexed in Pubmed: 20083621.

7. Elliott HR, Samuels DC, Eden JA, et al. Pathogenic mitochondrial DNA mutations are common in the general population. Am J Hum Genet. 2008; 83(2): 254-260, doi: 10.1016/j.ajhg.2008.07.004, indexed in Pubmed: 18674747.

8. Tuppen HAL, Blakely E, Turnbull D, et al. Mitochondrial DNA mutations and human disease. Biochim Biophys Acta. 2010; 1797(2): 113-128, doi: 10.1016/j.bbabio.2009.09.005, indexed in Pubmed: 19761752

9. Gorman GS, Schaefer AM, Ng Yi, et al. Prevalence of nuclear and mitochondrial DNA mutations related to adult mitochondrial disease. Ann Neurol. 2015; 77(5): 753-759, doi: 10.1002/ana.24362, indexed in Pubmed: 25652200.

10. Berardo A, Musumeci 0, Toscano A. Cardiological manifestations of mitochondrial respiratory chain disorders. Acta Myol. 2011; 30(1): 9-15, indexed in Pubmed: 21842587.

11. Duran J, Martinez A, Adler E. Cardiovascular manifestations of mitochondrial disease. Biology (Basel). 2019; 8(2), doi: 10.3390/biology8020034, indexed in Pubmed: 31083569.

12. Quadir A, Pontifex CS, Lee Robertson H, et al. Systematic review and meta-analysis of cardiac involvement in mitochondrial myopathy. Neurol Genet. 2019; 5(4): e339, doi: 10.1212/NXG.0000000000000339, indexed in Pubmed: 31403078.

13. Finsterer J, Kothari S. Cardiac manifestations of primary mitochondrial disorders. Int J Cardiol. 2014; 177(3): 754-763, doi: 10.1016/j. ijcard.2014.11.014, indexed in Pubmed: 25465824. 
14. El-Hattab AW, Scaglia F. Mitochondrial cardiomyopathies. Front Cardiovasc Med. 2016; 3: 25, doi: 10.3389/fcrm.2016.00025, indexed in Pubmed: 27504452.

15. Meyers TA, Townsend D, Meyers DE, et al. Mitochondrial cardiomyopathy: pathophysiology, diagnosis, and management. Tex Heart Inst J. 2013; 40(4): 385-394, indexed in Pubmed: 24082366.

16. Orsucci D, lenco EC, Siciliano G, et al. Mitochondrial disorders and drugs: what every physician should know. Drugs Context. 2019; 8: 212588, doi: 10.7573/dic.212588, indexed in Pubmed: 31391854.

17. Wahbi K, Bougouin W, Béhin A, et al. Long-term cardiac prognosis and risk stratification in 260 adults presenting with mitochondrial diseases. Eur Heart J. 2015; 36(42): 2886-2893, doi: 10.1093/ /eurheartj/ehv307, indexed in Pubmed: 26224072.

18. Majamaa-Voltti K, Peuhkurinen K, Kortelainen ML, et al. Cardiac abnormalities in patients with mitochondrial DNA mutation 3243A>G. BMC Cardiovasc Disord. 2002; 2: 12, doi: 10.1186/1471-2261-2-12, indexed in Pubmed: 12150714.

19. Elliott PM, Anastasakis A, Borger MA, et al. Authors/Task Force members. 2014 ESC Guidelines on diagnosis and management of hypertrophic cardiomyopathy: the Task Force for the Diagnosis and Management of Hypertrophic Cardiomyopathy of the European Society of Cardiology (ESC). Eur Heart J. 2014; 35(39): 2733-2779, doi: 10.1093/eurheartj/ehu284, indexed in Pubmed: 25173338.

20. Stalder N, Yarol N, Tozzi P, et al. Mitochondrial A3243G mutation with manifestation of acute dilated cardiomyopathy. Circ Heart Fail. 2012; 5(1): e1-e3, doi: 10.1161/CIRCHEARTFAILURE.111.963900, indexed in Pubmed: 22253408.

21. Wahbi $\mathrm{K}$, Larue $\mathrm{S}$, Jardel $\mathrm{C}$, et al. Cardiac involvement is frequent in patients with the $m .8344 \mathrm{~A}>\mathrm{G}$ mutation of mitochondrial DNA. Neurology. 2010; 74(8): 674-677, doi: 10.1212/WNL.0b013e3181d0ccf4, indexed in Pubmed: 20177121.

22. Brambilla A, Favilli S, Olivotto I, et al. Clinical profile and outcome of cardiac involvement in MELAS syndrome. Int J Cardiol. 2019; 276: 14-19, doi: 10.1016/j.ijcard.2018.10.051, indexed in Pubmed: 30482630.

23. Towbin JA, Jefferies JL, Towbin JA, et al. Cardiomyopathies due to left ventricular noncompaction, mitochondrial and storage diseases, and inborn errors of metabolism. Circ Res. 2017; 121(7): 838-854, doi: 10.1161/CIRCRESAHA.117.310987, indexed in Pubmed: 28912186.

24. Finsterer J, Stöllberger C, Kopsa W, et al. Wolff-Parkinson-White syndrome and isolated left ventricular abnormal trabeculation as a manifestation of Leber's hereditary optic neuropathy. Can J Cardiol. 2001; 17(4): 464-466, indexed in Pubmed: 11329546.

25. Finsterer J. Cardiogenetics, neurogenetics, and pathogenetics of left ventricular hypertrabeculation/noncompaction. Pediatr Cardiol. 2009; 30(5): 659-681, doi: 10.1007/s00246-008-9359-0, indexed in Pubmed: 19184181.

26. Val-Bernal JF, Mayorga M, Ortega C, et al. Histiocytoid cardiomyopathy and ventricular noncompaction presenting as sudden death in an adult male. Pathol Res Pract. 2017; 213(11): 1424-1430, doi: 10.1016/j.prp.2017.09.002, indexed in Pubmed: 28939283.

27. Rea G, Homfray T, Till J, et al. Histiocytoid cardiomyopathy and microphthalmia with linear skin defects syndrome: phenotypes linked by truncating variants in NDUFB11. Cold Spring Harb Mol Case Stud. 2017; 3(1): a001271, doi: 10.1101/mcs.a001271, indexed in Pubmed: 28050600.

28. Malfatti $E$, Laforêt $P$, Jardel $C$, et al. High risk of severe cardiac adverse events in patients with mitochondrial m.3243A>G mutation. Neuro- logy. 2013; 80(1): 100-105, doi: 10.1212/WNL.0b013e31827b1a2f, indexed in Pubmed: 23243073.

29. Khambatta S, Nguyen DL, Beckman TJ, et al. Kearns-Sayre syndrome: a case series of 35 adults and children. Int J Gen Med. 2014; 7: 325-332, doi: 10.2147/IJGM.S65560, indexed in Pubmed: 25061332.

30. Trivedi M, Goldstein A, Arora G. Prophylactic pacemaker placement at first signs of conduction disease in Kearns-Sayre syndrome. Cardiol Young. 2018; 28(12): 1487-1488, doi: 10.1017/ /S1047951118001609, indexed in Pubmed: 30326976.

31. Kabunga P, Lau AK, Phan K, et al. Systematic review of cardiac electrical disease in Kearns-Sayre syndrome and mitochondrial cytopathy. Int J Cardiol. 2015; 181: 303-310, doi: 10.1016/j.ijcard.2014.12.038, indexed in Pubmed: 25540845.

32. Rittoo D, Jones A, Lecky B, et al. Elevation of cardiac troponin $T$, but not cardiac troponin I, in patients with neuromuscular diseases: implications for the diagnosis of myocardial infarction. J Am Coll Cardiol. 2014; 63(22): 2411-2420, doi: 10.1016/j.jacc.2014.03.027, indexed in Pubmed: 24747102.

33. Scaglia F, Towbin JA, Craigen WJ, et al. Clinical spectrum, morbidity, and mortality in 113 pediatric patients with mitochondrial disease. Pediatrics. 2004; 114(4): 925-931, doi: 10.1542/peds.2004-0718, indexed in Pubmed: 15466086.

34. Feingold B, Mahle WT, Auerbach S, et al. American Heart Association Pediatric Heart Failure Committee of the Council on Cardiovascular Disease in the Young; Council on Clinical Cardiology; Council on Cardiovascular Radiology and Intervention; Council on Functional Genomics and Translational Biology; and Stroke Council. Management of cardiac involvement associated with neuromuscular diseases: a Scientific Statement From the American Heart Association. Circulation. 2017; 136(13): e200-e231, doi: 10.1161/CIR.0000000000000526, indexed in Pubmed: 28838934.

35. Newcastle Mitochondrial Disease Guidelines. Cardiac involvement in adult mitochondrial disease: screening and initial management [Internet]. 2010 [updated 2016, cited 2019 Oct 6]. from: http:// //www.newcastle-mitochondria.com/wp-content/uploads/2016/03/ /Updated-Cardiology-Guidelines-6.7.16.pdf (January 3, 2020).

36. van der Bijl P, Delgado V, Bootsma M, et al. Risk stratification of genetic, dilated cardiomyopathies associated with neuromuscular disorders: role of cardiac imaging. Circulation. 2018; 137(23): 2514-2527, doi: 10.1161/CIRCULATIONAHA.117.031110, indexed in Pubmed: 29866775.

37. Giannoni A, Aimo A, Mancuso M, et al. Autonomic, functional, skeletal muscle, and cardiac abnormalities are associated with increased ergoreflex sensitivity in mitochondrial disease. Eur J Heart Fail. 2017; 19(12): 1701-1709, doi: 10.1002/ejhf.782, indexed in Pubmed: 28233467.

38. Florian A, Ludwig A, Stubbe-Dräger B, et al. Characteristic cardiac phenotypes are detected by cardiovascular magnetic resonance in patients with different clinical phenotypes and genotypes of mitochondrial myopathy. J Cardiovasc Magn Reson. 2015; 17: 40, doi: 10.1186/s12968-015-0145-x, indexed in Pubmed: 26001801.

39. Yilmaz A, Gdynia HJ, Ponfick M, et al. Cardiovascular magnetic resonance imaging (CMR) reveals characteristic pattern of myocardial damage in patients with mitochondrial myopathy. Clin Res Cardiol. 2012; 101(4): 255-261, doi: 10.1007/s00392-011-0387-z, indexed in Pubmed: 22143423.

40. Karaa A, Haas R, Goldstein A, et al. Randomized dose-escalation trial of elamipretide in adults with primary mitochondrial myopathy. Neurology. 2018; 90(14): e1212-e1221, doi: 10.1212/ /WNL.0000000000005255, indexed in Pubmed: 29500292. 